\title{
CRAFTING THE WAY FORWARD: SUSTAINABILITY MODEL FOR INDIAN RURAL ARTISANS
}

\author{
Vidya Dayinee Sharan \\ Research Scholar, Department of Management, Himalayan University, India
}

\section{Dr. Ashutosh Priya*}

Associate Professor, Economics, MJP Rohilkhand University, Bareilly, Uttar Pradesh, India

\section{Mukul Kumar Shrivastava}

Assistant Professor, Ganga Global Institute of Management Studies, Begusarai, Bihar, India

*Corresponding Author

\begin{abstract}
Indian art and craft industries are as old as its civilization; it embodies its intellectual and aesthetic range. It has the full artistic, aesthetic, and attractive appearance, though, with time, the demand, philosophy, relevance, and nature of this industry have changed a lot.

Through this paper, we have tried to understand the fundamental issues faced by the rural artisans, and we have also dwelled upon how to make their livelihood sustainable in the long run. Artisans are the backbone of the Indian economy, but the only aspect is that they fall under an informal work setting. They are understood as custodians of Indian civilization, but on the contrary, they are deprived of all benefits, financial help, and all government-aided schemes.

This industry helps in employment generation majorly for rural people, allows them to improve their livelihood, making their purchasing power better day by day. Despite all these contributions, it is propelled by many issues, such as no government intervention, lack of skills, low marketing strategies, lack of up-gradation in technology, no financial help, and loss of market share. This industry is gradually losing its relevance and patronage in international and local markets due to fast-paced industrialization. Crafting the way forward calls for re-thinking, re-investment, and reorientation of the artisan industry to preserve the interest of Indian artisans and safeguard the civilization, heritage, culture, and history of India.

Investing in the art and craft industry attracts ample benefits. It offers a tremendous opportunity to rural communities by improving their social, economic, and environmental conditions way better and empowers rural households.
\end{abstract}


Key words: Rural artisans, Issues and challenges, Socio-economic developments, Handicraft.

Cite this Article: Vidya Dayinee Sharan, Ashutosh Priya and Mukul Kumar Shrivastava, Crafting the way forward: Sustainability Model for Indian Rural Artisans, International Journal of Management (IJM), 11(12), 2020, pp. 3028-3036.

http://iaeme.com/Home/issue/IJM?Volume=11\&Issue=12

\section{INTRODUCTION}

The rural artisans are the one who is supposed to be the custodian and guardian of Indian handicraft industry and preserve the Indian heritage. On the contrary, they are the most affected community deprived of all the social and economic facilities. According to the census, 2011, almost $70 \%$ of the total population lives in Indian villages, and most of them are associated with the informal segment. When the government devises developmental policy, they should formulate it following the rural development plan, which will help the rural handicraft industry raise the bar and improve quality. Still, it will also help to boost the confidence of artisans involved in such sectors. It will also make them self sufficient, sturdy, and reliant. This Informal sector also constitutes significantly to export industry, which directly impacts the economy.

The handicraft industry has always been the primary source of employment generation in India. It also helps to preserve Indian art, culture, and heritage. The artisans portray these beautiful emotions in different forms of art, craft, designs, etc. The design depicts the vibration of the creator and peculiarities of any civilization; hence handicraft industry helps to open the treasure of any culture or community. It also helps nurture cultural wealth by giving manure skills using hands, logic, and sensation.

Mahatma Gandhi has always believed in reviving the policies of villages, their craft. He tried to develop a system where one can be independent, self-sufficient in the real sense. Gandhi jee's model always revolved around sustainable development, which talked about the upliftment of rural industries by promoting handloom, Khadi and Handicraft, etc.

Worldwide the perception of Indian handicraft industries is quite popular and famous; however, the real picture is disheartening and bitter. The artisans have no fame, no recognition for the kind of work they do or perform; they are forced to be in this profession, although it does not give them enough income to survive. They do not get the government's required help, and they are left somewhere in the dark corners of the country. The fact is we do not have statistical data about rural artisans. Today, the custodians or the guardians of such industries are threatened and working in adverse conditions; thus, it has become a challenge to preserve their country's art, culture, and heritage.

\section{REVIVING HANDICRAFT INDUSTRY}

\subsection{Help them connecting to global buyers}

Nowadays, the E-commerce industry is booming like anything, and it has benefited the handicraft industry too to spread its wings. Many platforms have been launched immensely to boost the handicraft industry and take it to the next level to the global market. Handicraft industries, especially rural handicrafts, are the backbone of any economy. This industry carries excellent cultural value and the picture of art, culture, and heritage of any country through its design, art, etc. However, the fact is; this industry nowadays is highly dominated by machinemade fabric and stuff. Handloom products take a longer time to make because of the cost of raw material and labour cost, where machine-made products are quickly available and not much expensive. These problems are still not over; these rural artisans have no access to lucrative opportunities available, no access to the foreign and urban market, and a lack of exposure and 
awareness. They are also not able to make a good living. To make their life worth and productive, "e-platforms" have been launched by various companies, which help these artisans cater to different global and local demands and give them a sustainable, better living, and brighter future. It gives them a single platform to easily connect to international and regional buyers without much expense and get a high return for their hard and creative work.

\subsection{Strengthening marketing channel}

Marketing plays an important role in everyone's life. It has number of activities involved such as - marketing research / marketing design / product development / branding strategy / product / price / promotion / place / branding and packaging etc.

In the handicraft industry, it's tough to have a separate marketing wing to market its goods. It is generally expensive and owned by sole proprietary and artisans who have less knowledge about the marketing function since they are mostly involved in procuring raw materials. Producing handicraft goods is very time consuming and tiring as every art and craft differs in its design, shape, size, and colour schemes.

Strengthening the marketing channel of handicraft industries can be done through advertisement. It can be a great tool to promote and expand the business. Advertise also includes - handicraft exhibitions, participating in trade fairs, placing hoarding at a tourist destination, or study teams that study specific art and culture of the particular community and spread the knowledge to the rest of the world. There are few more critical measures, which can be taken to boost the marketing of handicraft industries:

- Sales promotion

- Creating awareness among buyers

- Introducing copyright

- Taking help of co-operative society

- Developing a marketing network.

- Etc.

\subsection{Government policies in place}

To develop the handcraft sector and address the challenges the artisans face government has launched various plans under the banner of the Government handicraft development programme with the help of the development commissioner.

It features following programmes:

\subsubsection{Ambedkar hastshilp viaks Yojna}

This scheme enables artisans to form self-help groups, which provides a smooth mobilization of resources. They work on the design schemes according to current market trends and work on contemporary arts and crafts. They try to develop new technology and techniques to improve production, design prototypes, etc.

\subsubsection{Mega cluster scheme}

Here, they keep work on scaling up the infrastructure and production. Being an unorganized industry; it is not able to retain that pace with changing market scenario. This scheme aims to create employment opportunity for many and give them a better life prospect. 


\subsubsection{Marketing support and service scheme}

Here artisans are given all kinds of assistance, whether it is financial or technical. They are given all sorts of exposure, which is required for them to expand their business. They are encouraged to participate in various exhibitions, marketing events, and in various other activities that are taking place across Globe, etc. It has also helped strengthen their marketing campaign and give them a vast exposure, which further helped artisans attract new customers, create high demand, and give this industry a boom.

\subsubsection{Research \& Development scheme}

The research and development wing is developed for the continuous improvement of this art and craft industry. It is also done with surveys and studies to gain the maximum information about this field and improve it further.

\section{OBJECTIVE}

This study is a justifiable attempt to examine rural handicraft artisans' opinions about the marketing channel, business expansion in the handicraft sector.

Observing the situation at the grass-root level, it was felt that there must be proper means, methods, and efforts to highlight the latent potential and hidden wealth of creativity through government schemes and build a sustainability model that will enrich the lives of artisans in a longer run.

\section{RESEARCH METHODOLOGY}

The research undertaken was descriptive and analytical. The data was collected in the catchment area, where artisans primarily engage themselves in the said profession. The response was provided by 110 respondents, out of which, 75 was complete and useful to record for evaluation and analysis. The data collected was analyzed through Descriptive statistics, and One-sample Chi-square test for association was carried out for testing the hypothesis.

\subsection{Postulation of Hypothesis}

The null hypothesis was postulated to analyze respondents' association based on demographical variables and their awareness of governmental / Non-governmental schemes.

$\mathrm{H}_{01}$ : There is no association of Gender and their awareness level of artisans

$\mathrm{H}_{02}$ : There is no association of Age and their awareness level of artisans

$\mathrm{H}_{03}$ : There is no association of Education and their awareness level of artisans

$\mathrm{H}_{04}$ : There is no association of income and their awareness level of artisans

\subsection{Data Collection and Analysis}

The awareness at the grass-root level is dismally low. The shops who do send the items to outside their state or even export are a few only. The schemes that the government announces for the benefit of artisans, especially who have meagre income, seldom benefits them. The data was collected regarding awareness of artisans' schemes concerning their demographic profiles, i.e. age, gender, education, and income. These factors hugely influence the outcome. 
Table 1 Demographic Profiling

\begin{tabular}{|c|c|c|c|}
\hline Variable Factors & Variability & Count & Percentage $(\%)$ \\
\hline \multirow[b]{2}{*}{ Gender } & Male & 47 & 62.7 \\
\hline & Female & 28 & 37.3 \\
\hline \multirow{5}{*}{ Age } & Below 15 year & 1 & 1.3 \\
\hline & $(15-30)$ year & 23 & 30.7 \\
\hline & $(30-45)$ year & 37 & 49.4 \\
\hline & $(45-60)$ year & 10 & 13.3 \\
\hline & Above 60 year & 4 & 5.3 \\
\hline \multirow{4}{*}{ Educational Qualification } & Up to High School & 24 & 32.0 \\
\hline & Upto Intermediate & 42 & 56.0 \\
\hline & Up to Graduation & 5 & 6.7 \\
\hline & Others & 4 & 5.3 \\
\hline \multirow{5}{*}{$\begin{array}{l}\text { Income } \\
\text { LPY (Lakhs Per Year) }\end{array}$} & Under INR 2.5 Lakhs/ Year & 47 & 62.7 \\
\hline & INR $(2.5-3.5)$ Lakhs/ Year & 15 & 20.0 \\
\hline & INR (3.5 - 5.0) Lakhs/ Year & 8 & 10.7 \\
\hline & INR (5.0 - 10.0) Lakhs/ Year & 3 & 4.0 \\
\hline & INR $10.0(+)$ Lakhs/ Year & 2 & 2.6 \\
\hline
\end{tabular}

The above table shows that the males are more in number as artisans compared to the female counterpart. The age group of (15-45) years constitutes almost $80 \%$ among the respondents. Simultaneously, nearly $88 \%$ of the respondent artisans have a low level of education, i.e. up to intermediate level. More than $90 \%$ of the respondent artisans earn up to 5 lakhs in a year, out of which $60 \%$ earn up to 2.5 lakhs in a year.

The One-Sample Pearson's Chi-square test was performed to find the association of demographic variables with the respondent artisans' awareness level. The awareness level among the respondents was $61.3 \%$.

Table 2 One-Sample Chi-Square Test

\begin{tabular}{|l|l|l|}
\hline Variables Tested for Result & Pearson'schi-square Value & $\begin{array}{l}\text { Significance } \\
\text { Value }\end{array}$ \\
\hline Age of artisan and awareness level & 59.333 & 0.000 \\
\hline Gender of artisan and Awareness level & 4.813 & 0.028 \\
\hline $\begin{array}{l}\text { Education of artisan and Awareness } \\
\text { level }\end{array}$ & 51.987 & 0.000 \\
\hline Income of artisan and Awareness level & 92.400 & 0.000 \\
\hline
\end{tabular}

* Significance level is 0.05

Table 2 above exhibits the following results against the postulated Null hypotheses.

- $\mathrm{H}_{01}$ : There is no association of Age of respondent artisans and their awareness level.

The table shows the test's value to be 59.333 with the significance to be 0.000 , which is below and well within acceptable significance level of 0.05 (or 5\%). Thus, the null hypothesis is rejected. This statistically means that awareness level varies with age. 
- $\mathrm{H}_{02}$ : There is no association of Gender of respondent artisans and their awareness level.

The table shows the test's value to be 4.813 with the significance to be 0.028 , which is below and well within acceptable significance level of 0.05 (or 5\%). Thus, the null hypothesis is rejected. This statistically means that awareness level varies with gender.

- $\mathrm{H}_{03}$ : There is no association of Education of respondent artisans and their awareness level.

The table shows the test's value to be 51.987 with the significance to be 0.000 , which is below and well within acceptable significance level of 0.05 (or 5\%). Thus, the null hypothesis is rejected. This statistically means that awareness level varies with the educational level.

- $\mathrm{H}_{04}$ : There is no association of income of respondent artisans and their awareness level.

The table shows the test's value to be 92.400 with the significance to be 0.000 , which is below and well within acceptable significance level of 0.05 (or 5\%). Thus, the null hypothesis is rejected. This statistically means that awareness level varies with the income level.

\section{LITERATURE REVIEW}

- The craft Council of INDIA (2011), according to their report on "Craft Economy," states that the majority of Indian rural artisans use an indigenous mode of production for producing handicraft goods or the process they use for production. These rural artisans are the backbone of the economy, where 7 million artisans are on record, and nearly 200 million artisans are off the record. Their livelihood, to the extent, entirely depends on Handicraft.

- Dasra (2013), according to their report on "Indian Artisans," encompasses that handicraft tradition passes from generation to generation and create means for sustainability. It also carries the identity of Indian culture and heritage. Defined by UNESCO, this industry has massive potential for income generation by fostering its cultural assets. This industry produces tangible and intangible artistic and creative products ranging from embroidery to pottery, which carries different variations and regional vibrations, varying from one product to another. This report also talks about the contributions made by various Governmental / Non Governmental / Private and nonprofit organizations in this industry's development.

- Dar \& Parrey (2013), talk about the potential opportunity and challenges this industry might have in their article. They have mentioned how this handicraft industry is exquisite and diverse, how India is a treasure house of this entire handicraft industry. They have also talked about the different forms of raw materials sourced from other parts of the country. The raw materials are metal-ware, wood-ware, textiles, leathercraft, carpets, wood design, shawls, pots, ceramics, pottery, hand carvings, jewellery, and many more. They have also talked about the employment opportunity for the entire society and also helped in socio-economic development.

- R. Rao (1979) talks about the history of Indian art and culture in his book. He states how artisans have changed the way of handicraft industry and how significantly it has contributed worldwide. In his book, he enlightens the image of the art, culture, and heritage of India. In India, ancient sculptures and carvings can be witnessed or testified by visiting the Indian temples. He also talks about the employment opportunity this industry provides and how substantially this industry helps in foreign exchange and contributes to boosting the Indian economy.

- Subrahmanyabala (2004) mainly talks about integrating modern technology and ancient art, which can boost the economy and provide many employment opportunities. He also 
says that with the help of this integration process, the small, medium scale industries can open its wing in the International market. The author adds that due to globalization, small and medium enterprises have suffered a lot. However, this handicraft industry has vast potential to provide financial assistance, employment opportunities, boost national income. It has got all the necessary and required help from the government and supporting agencies.

- Singh \& Fatima (2015), in their article "Role of the handicraft sector in the Economic Development of Uttar Pradesh," have explained the creative work of an individual and their hard work behind the final goods produced. How hard they work solely on a piece of work to make it unique from another piece using their hand and few tools. As a result, each art form is unique in some way and inspires many generations to come. Each end product entails different stories of the same good produced - as it carries different regional values, different styles, and different mind-set, which creates all-together a unique and beautiful product.

- Yang, Shafi, Song and Ruo Yang (2018), they have mentioned in their article that the handicraft industry is a way to create employment and income and works as a poverty reduction tool. It also promotes cultural and artistic forms of any culture or heritage from one generation to another. This paper also talks about the modernization of this sector and the use of technological advancement while producing goods, which is directly eating up the traditional market of the handicraft industry, and also talks about the struggle of these artisans, which have increased over a period of time. Globalization and competition forces many artisans to abandon their traditional work and move to cities to earn their livelihood. As a result, many art forms and craftsmen skills have been faded away.

- The future of this market is very much vulnerable as the young generations are not much keen. It is not giving them a better future prospect or a healthy livelihood. It also lacks in various ways - lack of innovation and technology, lack of necessary infrastructure, and lack of government intervention. It is not drawing the attention of young generations and appeals to them much to perform such a task.

- Shah \& Patel (2016), They have discussed how e-commerce is changing and paving the way for rural artisans in India by some government and non-government agencies' efforts and how they are helping to uplift the socio-economic status of rural artisans. They have also done the SWOT analysis using e-commerce. It entails how rural arts and crafts have created a tremendous job opportunity for many. They also earn their livelihood from agriculture. They emphasized the Government strategy, which should always be aligned with the rural development strategy. When Indian villages get all necessary and essential support from the government, they can efficiently contribute to the Indian economy. The rural industries are culturally rich, diverse, and every community possesses unique art forms, which helps shape rural industry way better than before.

- Tiamni (1981) shows that the government plays an essential role in boosting the rural economy and helping farm-based people generate income by launching various programs to improve their livelihood. They try to generate revenue through off-farm based business, such as engaging them in tourism-oriented activity, where these workers are involved in producing handicraft goods, cottage business. These businesses are also turning out to be the mode of income and employment generation to the rural people. Many researchers have studied this area in the length and breadth of the artisan industry. 
- Rameshwar (2003), in his article "Through History," he emphasized the tourism sector and handicraft sector of India and how it has been developed over a period of time. He has also explained; how these artefacts were used even in those times, when there were kings and emperors: who ruled us. He also discussed how marketing and publicity were used then. It was all done through travellers and explorers. Those periods were the period of unemployment and poverty. The craftsmen were not allowed to choose products instead; they were forced to produce raw cotton. But with the passing time and the help of industrialization; the entire picture of handicraft industries has changed a lot, and artisans have now been given more freedom to exercise their creativity and ideas in the final goods produced by them.

\section{CONCLUSION}

Indian economy majorly relies on agriculture besides agriculture; it also depends on the rural Handicraft, which is a booming industry and has created employment opportunities for many and paved the way for a better future. Handicraft industry or cottage industry makes a huge demand worldwide. Still, at the same time, they face various challenges, especially, in terms of marketing channels, availability of raw materials, lack of awareness and, no standard policy in place to regulate these industries.

This paper has seen how e-commerce has benefited this industry and have taken it to a different level altogether. E-platforms have helped rural artisans directly sell their products in the market and make a good profit, which caters to solving many problems. E- Platforms help reduce the middlemen or the mediator who earlier used to take out the substantial amount or share and left nothing for the artisans. E-platform has made their life simple and easy. ECommerce also helps these artisans reap widening the market as it has no geographical boundaries. It also helps them to boost the marketing channel.

The make in India concept has boosted such industries while giving them shape and empowering them. Few online brands which helped the artisan industry to cater to Global demand; such as - Tijori (handicraft and apparel), Triveni Chicken arts (Lucknow chicken art), Ethnic craft (Rajsthan art and craft), and many more.

\section{REFERENCES}

[1] Shah, A. \& Patel, R. (2016). E-commerce and Rural Handicraft Artisans. Voice of Research, Vol. 5 (3), ISSN: 2277-7733, pp. 24-29.

[2] Dasra. (2013). Crafting a livelihood building sustainability for Indian artisans. The Edmond De Rothschild Foundation.

[3] Preservation of Cultural Heritage Embodied in Traditional Crafts in the Developing Countries. A Case Study of Pakistani Handicraft Industry Yongzhong Yang, Mohsin Shafi April 2018.

[4] Shah, A., \& Patel, R. (2016), E-commerce and Rural handicraft artisans. Voice of Research, Vol. 5, Issue 3 December 2016 ISSN 2277-7733 pp24-29

[5] Sankaran, P. N. (2011). Artisans of India: Towards Inclusive Development. Serial Publications, New Delhi.

[6] S.S.Solanki (2008). Unorganized Sector of Workers: Rural Artisans, India, Science and Technology, S\&T for Rural India and Inclusive Growth, Retrieved from HTTP:// www.nistads.res.in/indiasnt2008/t6rural/t6rur5.htm

[7] Shah, A.N. (2015). Gramin Bharatma Hastakala Kshetre Kaushalya Vikas- Ek Asha. YOJANA, (Special Gujarati edition on Skill India Mission), Year:43, Volume No. 7 (OCT2015), Cont. Vol. No. 778, 63-66. ISSN: 0971-8397. 
[8] Tiwari, Aditi and Dutta, Bedanta. Indian Handicrafts Industry: Evaluating Inclusivity Of Current Business Models retrieved from http://tejas.iimb.ac.in/articles/

[9] Tiamni, K.K. (1981). Employment generation through handicraft co-operatives: The Indian Experience. International Labour Review, 120(4), 506.

[10] Singh, A. K., \& Fatima, S. (2015). Role of handicraft sector in the Economic Development of Uttar Pradesh. International Journal of research Granthaayalah, Vol. 3(1), pp 58-64.

[11] Subrahmanyabala, M.H. (2004). Small Industries and Globalization: Implications, Performance and Prospects. Economic and Political Weekly. Vol. 39(18), 1826-1834.

[12] Rao, R. (1979). Small Industries and the Developing Economy in India. New Delhi: Concept Publishing.

[13] Dar, M. A., \& Parrey, A.H. (2013). Socio-Economic Potential of Handicraft Industry in Jammu \& Kashmir: Opportunites and Challenges. Abhinav, II, pp 20-28.

[14] Jani, V. A. \& Pandya, B.A. (1994). Rural artisans and Modernization. Illustrated Book Publishers, Jaipur, ISBN:81-85683-10-7

[15] Jaitly, J. (1990). The Craft Traditions of India. Luster Press, New Delhi.

[16] Patel, B. \& Chavda, K. (2013, July). Rural Entrepreneurship in India: Challenge and Problems. International Journal of Advance Research in Computer Science and Management Studies, 1(2), ISSN: 2321-7782

[17] Naidu, L.K. (1988). Bank Finance For Rural Artisans. Ashish Publishing House, New Delhi.

[18] S.S.Solanki (2008, May, 10). Sustainability of Rural Artisans. Economic and Political Weekly, May, 10, 2008, p. 24-27.

[19] Yadav, Monika (2012, November). Role Of Artisans In Rural Development: A Study Of Mahindergarh District. International Journal of Research in Economics \& Social Sciences, Volume 2, Issue 11, ISSN: 2249-7382.

[20] Sanjay Mahapatra, (2011). Problem Associated with artisan in Marketing of Handicraft in Orissa, India, Management Review; An International Journal, Vol.6, No.1, 2011

[21] Sarvamangala, D. R. (2012). Challenges and Opportunities for Rural Cottage \& Handicraft Industries in India (ISSN 2250-1991). Paripex - Indian Journal of Research, 1 (9), 9-10.

[22] Rao, A. Ch., Ramachandrudu, G. \& Rao, S. N. (2004). Rural Out Migration in a Low Population Growth Setting, Census 2001 and Human Development in India. Serial Publications, New Delhi, p.116- 127.

[23] Kotler, P., Marketing Management, Thomson Press (India) Ltd, New Delhi, (2003)

[24] Waqar Ahmad Khan1 and Zeeshan Amir2(2013). Study of Handicraft Marketing Strategies of Artisans in Uttar Pradesh and Its Implications. Research Journal of Management Sciences, Vol. Vol. 2(2), pp23-26.

[25] www.craftofgujarat.com

[26] www.craftrevival.org

[27] www.craftroots.org

[28] www.handicrafts.nic.in

[29] www.kala-raksha.org

[30] www.voiceofresearch.org 